\title{
A Comparative and Contrastive Study of Sadness Conceptualization in Persian and English
}

\author{
Mohammad Reza Moradi ${ }^{1} \&$ Shahrzad Pirzad Mashak ${ }^{2}$ \\ ${ }^{1}$ Dep. of English, Payame Noor University, Tehran, Iran \\ ${ }^{2}$ Sama Technical Teachers College Dezful Branch, Islamic Azad University, Dezful, Iran \\ Correspondence: Mohammad Reza Moradi, Department of English, Payame Noor University, Tehran, Iran. Tel: \\ 98-916-341-9313. E-mail: r_mohammedmoradi@yahoo.com
}

Received: December 5, 2012

Accepted: April 19, 2013

Online Published: May 3, 2013

doi:10.5430/elr.v2n1p107

URL: http://dx.doi.org/10.5430/elr.v2n1p107

\begin{abstract}
Metaphors are both of mind and language as was proposed by contemporary metaphor scholar (Lakoff, 1993). Sadness as a basic metaphor was investigated in the present study to mainly uncover the similarities and differences in sadness conceptualization and the governing pattern in both Persian and English.

For the purpose of the study, total 115 expressions were collected from different sources in the two languages. English data was extracted from the work of Kovecses (1990, 2005), British National Corpus, and NTC dictionary of idioms. Persian expressions, in turn, were extracted from Amsal \& Hekam Dehkhoda (1960), and Estelahat-e-Amiyane Anvary (2004 ).

Lakoff \& Johnson's Conceptual Metaphor Theory was adopted as a main instrument to uncover the conceptual system of both languages under study. In addition, to identify the governing pattern in Persian and English Kovecses's linguistic expressions of metaphor model (2003) was adopted to identify the dominant pattern in this study.

The results revealed that, although some salient differences were observed in the case of sadness conceptualization at the general level, the principal pattern in this study was partially the same ( $\mathrm{PS}=47 \%$ ), that is, those with the identical conceptual metaphor but different literal meaning. It was concluded that although both languages share most sadness conceptual metaphors, some differences were observed at generic-level relating to the existence/nonexistence of metaphors in Persian and English.
\end{abstract}

Keywords: Conceptual metaphor, Sadness, Metaphorical expression, Literal meaning, Persian, English

\section{Introduction}

Metaphor as a ubiquitous cognitive-linguistic tool in everyday language is used consciously and unconsciously to make abstract concepts more tangible and concrete. Emotions as abstract, unobservable and internal states are proved to be a best target realm to be articulated by means of metaphor. Every emotion as studied by Kovecses (1990, 2000, 2005) is conceptualized through several source domains. The concept of sadness, as a basic emotion, is also conceptualized with several source domains in Persian and English which then leads to the construction of sadness conceptual metaphors in the mind and manifestation in everyday language of language speakers. The pioneering works on emotion metaphors (Lakoff \& Kovecses, 1973) revealed that emotion conceptualization in many languages of the world is universal due to the similarity of human nature and the physiological and behavioral responses of the body in reaction to emotions which in turn lead to similar experiencing of abstract concepts (i.e. emotion). This universality in many related and unrelated languages became the main concern of many researchers to uncover the conceptual system of language speakers and consequently discovering the similarities and differences between their languages and English.

\section{Comparative studies on the concept of sadness}

In this theoretical framework, the agenda of cognitive semantics or conceptual metaphor, a lot of studies concerning basic emotions have been carried out. Studies on emotion metaphors are plentiful but most of them worked on anger, happiness, and love in many languages. For example, Matsuki (1995) conducted a research on metaphors of anger in Japanese; Yu (1995) examined metaphorical expressions of anger and happiness in Chinese and English; Soriano 
(2003) studied anger metaphors in Spanish and English. Their findings support Kövecses's (1990, 2000, 2005) emotion metaphors and cultural variation on emotion conceptualization but works on sadness were insufficient. So, it was the main reason to conduct the present study especially nothing has been done in the two languages, Persian and English comparatively. Likewise, the study of conceptual metaphors of SADNESS in English has also been abundant: SAD IS DOWN -which is the major conceptual metaphor proposed by Lakoff and Johnson (1980: 15-18); in addition, a list of 14 metaphors of SADNESS in English is offered by Kövecses (2000:25-26).

Kovecses's (2005) work on sadness metaphor revealed some conceptual metaphor in English which first was studied by Barcelona (1986). The conceptual metaphors "SADNESS IS DOWN", "SADNESS IS DARK", "SADNESS IS A FLUID IN CONTAINER", "SADNESS IS ENEMY", " SADNESS IS A MOBILE ENTITY", "SADNESS IS A MOVABLE OBJECT" and "SADNESS IS BURDEN". Wenfeng' s (2008) work on sadness in Chinese and English revealed the identical conceptual metaphor in Chinese as in English.

\section{Method}

To perform this study, total 100allegoricalterminology describing sadness as the research materials were compiled randomly from different sources in both Persian and English. The model as well as the mechanism of the investigation and comparison of the two sets of data collected in the two languages were, though, adopted from Lakoff and Johnson (1980) as they have been presented in their invaluable book of 'Metaphor We Live By' and Kovecses's model (2003) of linguistic expressions of metaphor. The research mass was gathered from several sources, from both written and spoken discourses in both Persian and English. English expressions were extracted from works of Kovecses on emotions (1990, 2005), Barcelona (1986), Lakoff and Johnson (1980), NTC' Dictionary of Idioms and British National Corpus (BNC). Persian Expressions were selected from Amsal-Al- Hekam (Dehkhoda, 1960), Farhang-eKenayat-e Sokhan (Hassan Anvary, 2004).

\section{Procedure}

Two phases, namely grouping or juxtaposing the conceptual patterns in the languages and comparative analysis taking in to account to conduct this research. First, the metaphorical expressions were grouped under their general and specific source; then they were compared based on the two discriminative parameters, conceptual metaphor and literal meaning. Additionally, each Persian expression with its English phonetic sign and its English literal conversion were scheduled in each conceptual metaphor. If expressions in each group can be found in other language with the identical literal meaning and conceptual metaphor, they were measured as utterly the same, while two expressions under the same conceptual metaphor with different literal meanings were measured as partially the same and if an expression was an instantiation of a different conceptual metaphor which was absent in the other was measured as utterly different. At the end of the comparison, the similarities and differences among metaphorical expressions in both languages were observed to calculate the percentages of the three patterns namely utterly the same, partially the same, and utterly different, and consequently, the dominant pattern in Persian and English in linguistic expression of the concept was distinguished. In this study, Persian expressions were represented by their phonetic signs and literal conversion in English (thereafter lit.).

\section{Data analysis}

Having selected Lakoff and Johnson' s (1980) Conceptual Metaphor Theory and Kovecses' (2003) as the model of linguistic expressions of Metaphor, records from the study were both qualitatively and quantitatively analyzed. Metaphors for sadness were analyzed from a cognitive linguistic perspective in this study and many source domains were identified throughout the study discussed in subsequent subsections. In addition, the differences and similarities were discussed in each group (i.e. source domain). The analysis of the present data demonstrated the following conceptual metaphors in both Persian and English and also some differences were observed which are presented during the analysis.

\subsection{Orientational metaphor}

Orientational metaphor as the first group of tangible metaphor gives sadness a downward orientation (Lakoff \& Johnson, 2003.p. 15). Barcelona (1986) also studied sadness metaphors and found that the conceptual metaphor "SADNESS IS DOWN" is very common and usual in English language usage. This is due to its experiential basis. People who are sad often exhibit a slouching posture, drooping shoulders, corners of the mouth turning down, etc. This correlation between the state of sad and expressive and behavioral responses motivates the metaphors "SADNESS IS DOWN" and "SADNESS IS LOW". The metaphor "SADNESS IS DOWN"is closely linked to our physical experience while feeling this emotion. Lakoff and Johnson (1980:15) state that a "drooping posture typically goes along with sadness". As examples "I am feeling kind of low right now.", "I have decided not to 
contact my ex because that gets me down as well.", "However, she's been getting quite depressed lately."The examples hint that an increase of SADNESS is experienced as being physically nearer to the ground. Additionally, the second example shows that another person is able to evoke feelings of SADNESS, which is conceptualized as pushing someone physically downward. In the last example, the lowest possible physical state is mapped onto the most intense feeling of SADNESS. Being depressed means being pressed down to the ground, which implies the impossibility of being in any lower position. The words down and low directly bring in to play by English speakers to express their feeling of sadness, such as, "I am feeling down", "He brought me down with his remarks", "Down in the mouth", "He is really low these days", "I am feeling kind of low". Opposing to English, Persian does not apply the words low/ down directly. The down/low posture can be inferred from Persian metaphorical expressions such as,

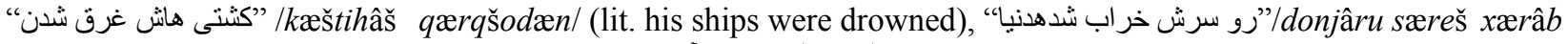

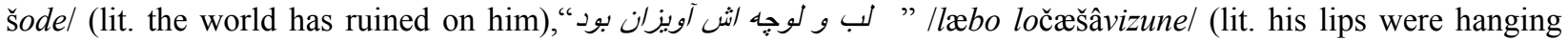

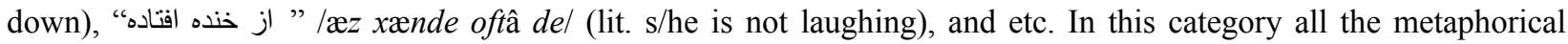
expressions are partially the same, it means, they represent the conceptual metaphor "SADNESS IS DOWN/LOW" but their linguistic manifestations are not the same. The only utterly the sameness here can be seen in the English expression "I am in low spirits" which in Persian means "روحيه ام بايينه" /ruhijeæm pâine/ when the words down and low collocate with the word spirits in Persian mean sadness and depression (for more examples see appendix 3). As Lakoff and Johnson (1980:18) stated that metaphors are rooted in physical and cultural experience and they are not randomly assigned one of the significant cultural differences in Persian and English was revealed in this category. When someone is in severe sadness and sorrow is very depressed, English expresses it with word "depth" for instance, "in the depth of sadness" but the word "وج" /odz/is used in persian" /odz/ (lit. climax)which literary means "climax" the opposite of depth and leads to the metaphorical mapping "INTENSE SADNESS IS BEING AT

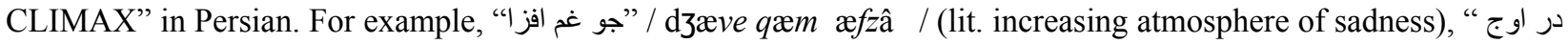
" نار احتى بود" /dær odze nâ râ hæti bud/ (lit. be at the climax of sadness and sorrow).

\subsection{Mobile entity/Being metaphor}

The second highest number of metaphorical expressions detected in the present research language data of English and Persian can be assigned to the metaphor personified sadness as a mobile entity which gives rise to the metaphorical mapping "SADNESS IS MOBILE ENTITY" and "SADNESS IS BEING" metaphor. These metaphors consider sadness as something which can move, come, go, return and can be put aside. It is evident in the following English examples: "When sadness comes, we need to allow ourselves to feel it fully.", "So it is okay for her to wish her sadness will return,..", "When sadness comes ", "Sadness came out ", "Put it aside". "SADNESS IS A LIVING ORGANISM" metaphor is another conceptual metaphor identified by Barcelona (1986) in English. This metaphor personifies sadness as a living being that can come back or return to someone, or can be removed, and killed and take its life as no one would like as a host. English expression such as, "He drowned his sorrow in drink". Persian,

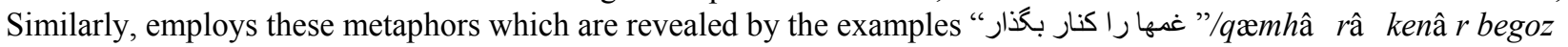
âr/ (lit. put sadness aside), "غم و غصه بسر اغش اومد /qæamoqose be sorâ qesh umæd/ (lit. sadness and sorrow came to him) and“"غم را از خودت دور كن" /qæm râ azxodæt durkon/ (lit. away sadness from yourself).These examples in both English and Persian point out that SADNESS is personified as actively moving and coming to us human beings whenever it wants to. When SADNESS is present, we feel sad. In general this metaphor suggests that a person does not have much influence on the emotion SADNESS. One can wish that SADNESS may come or go and even invite the emotion, but in the end the decision is made by SADNESS itself." All the above English metaphorical expressions in this category can be rendered into Persian serving the same metaphorical meaning and are utterly the same.

\subsection{Container metaphor}

Container metaphor as a highly productive metaphor in the case of emotions identified by Kovecses (1990) is shared within all emotions and is considered as a general source domain for them. Emotions can be container or a fluid in a container. In the case of sadness both "SADNESS IS A CONTAINER" and "SADNESS IS FLUID IN A CONTAINER" (Kovecses, 2000) with lack of heat leads to metaphorical mapping "BEING SAD IS BEING LACK OF HEAT" were recognized with research data. They are regular in both English and Persian. Containers in describing sadness are body parts including eyes, heart, chest and body itself. So the metaphorical mappings "EYES ARE CONTAINER FOR SADNESS", "HEART IS A CONTAINER FOR SADNESS", "CHEST IS A CONTAINER FOR SADNESS" and "BODY IS A CONTAINER FOR SADNESS" is depicted from research data in Persian and English. Following English terminologies express these kind of container metaphors "heart filled with sadness ", "There was a sadness in Alina's eyes", "May have sadness ingrained in them", "Loosing his father put his fire out", "he was filled with sadness" and Persian expressions such as, "تون جشاش غم را ميشه ديد"/tučeš âš qæm râ miše 


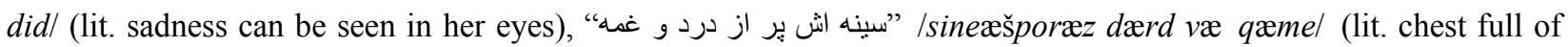
sadness), “ب با دلى آكنده از غمو اندوه /ba deli âkændeæz qæm væænduh/ ( lit. heart filled with sadness and sorrow ),“"

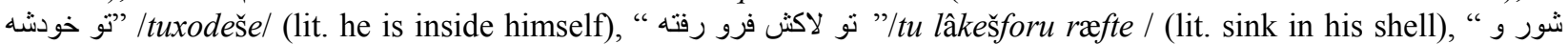
"هرد و بى روح شده مثل مرده" "هيجانش را از دست داده /særd væ bi ruhšode, meslemordeh/ (lit. he is like the dead cold with no spirit). The two last examples in Persian represent another kind of metonymical mapping "LACK OF VITALITY STANDS FOR SADNESS" which leads to metaphorical mapping "SADNESS IS LACK OF VITALITY", similarly, English expression "it was a disheartening news" represents it. One of the cultural difference which exist between English and Persian lies in the fact that sadness is considered as a bird which nest in the body parts of a sad person including eyes and heart in Persian. The metaphorical mapping "EYES ARE NESTS FOR SADNESS" and "HEART IS A NEST FOR SADNESS". Persian

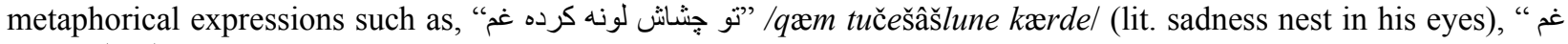
" اكنج دلث لونه كرده / qæm konje delešlune kærde/ (lit. sadness nest in his heart) demonstrate this kind of mapping. Another difference which is illustrates with Persian metaphorical expressions is in fluid in a container metaphor for

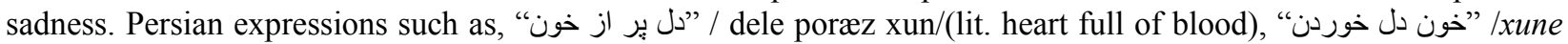
del xordæn/ (lit. drinking heart blood ), "دلم خونه ازاين دنيا" / delæm xuneæz in donjâ/ (lit. my heart is blood) represent blood as sadness fluid in sad person heart and leads to metonymic mapping "DRINKING HEART BLOOD STANDS FOR SADNESS" and "HEAR IS FULL OF BLOOD STANDS FOR SDNESS" in Persian. The first metonymical mapping represents sadness as an edible substance which can be drunk or eaten. Metaphorical example "غصه خوردن" /qosexordæn/ (lit. eating sorrow or sadness) illustrates sadness as an eatable substance and construct another conceptual metaphor "SADNESS IS EDIBLE" which is highly conventional in Persian.

\subsection{Dark metaphor}

In the case of "SADNESS IS DARK" metaphor, motivation is provided by the tendency of people who feel sad to prefer dark to light places (Kovecses, 2000). It is opposed to the state of happiness in which people looks brighter than usual and have tendency to communicate and show their happiness to others. According to data, dark metaphor is common in English and Persian and it is shared between them. English expressions, like "He is in a dark mood", "I am afraid the situation looks very bleak", "Through the dark year", "Endless darkness" and Persian expressions such as, "دنيا به جشمش تيره شد" " donjâ be češmâšs tire šod/ (lit. the world became dark in his eyes), "بناب "شام غم هايم بتاب /bær šâme qæmhâjæm betâb/ (lit. enlighten my night of sadness), “ سياه بخت شد "/siyâ $h$ bæxtšod/ (lit. be black fortune).

\subsection{Color metaphor}

Since colors are part of culture, they will create misunderstanding for the foreign language learners. "SADNESS IS BLUE" is a special metaphor in English to express one's sad feelings. English conventional expressions such as "Feeling blue", "Get the blues", "Blue Monday" are examples of blue metaphor for expressing someone sadness. Since literal meaning and translation of blue metaphor make no sense for Persian speakers and misunderstanding will occur. These kinds of metaphorical expression must be rendered into metaphorical meaning to avoid misunderstanding. So they are considered utterly different because of the absence of metaphors that use the color blue expressing sadness in Persian. Persian mostly applies metaphor that use the color Black in expressing sadness and the metaphorical mapping "SADNESS IS BLACK" is represented with metaphorical expressions in Persian such as, "سياه بخت شدن"/sijâ $h$ bæxtšodæn/ (lit. be a black fortune), "دنيا به جشمش سياه شده" "donjâ be češmešsijahšode/ (lit. the world became black in his eyes), “ شده روزكارش سياه" /ruzegâ ræšsijâh šode/ (lit. his life became black ). Black metaphor is more conventional in Persian than in English. Another cultural difference in Persian and English is the metaphor "SADNESS IS COLOR" demonstrates with the metaphorical expression "رنح غم كرفته"/rænge qæm gereftel (lit. he has got the color of sadness).

\subsection{Opponent/Friend metaphor}

Another conceptual metaphor of SADNESS is the personification of "SADNESS AS AN ENEMY" presented by data in English and Persian. Following expressions in English reveal this kind of metaphor such as, "When joy comes into our life we experience it freely, but when sadness or grief is present, we often struggle with them", In these examples, SADNESS is presented as an opponent to fight with and even eliminate. Similarly, Persian uses opponent metaphor in describing someone's sadness such as, "بِّروز شدن بر غم" /piruzšodæn bær qæm/ (lit. to

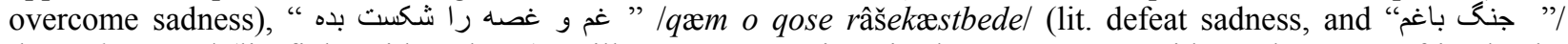
dzængbâ $q æ m /$ (lit. fight with sadness). Still, some expressions in data seem to consider sadness as a friend. The research data disclosed another conceptual metaphor for sadness as "SADNESS IS A FRIEND" was revealed from the expressions such as, "I propose embracing the sadness in our lives and sending love to ourselves.", "In addition to accepting our sadness as a normal part of life, and allowing it to be present". This conceptualization of SADNESS 
suggested to conceive of SADNESS as a friend, or to simply accept the presence of SADNESS as a companion. Similarly, Moslems in general and Persians in particular employ FRIEND metaphor in conceptualizing sadness and it is evident in expressions such as, "جلا ميدهر انساناكريه روح")/gerjeruheensân râdzælâmide/ (lit. crying polish human' s

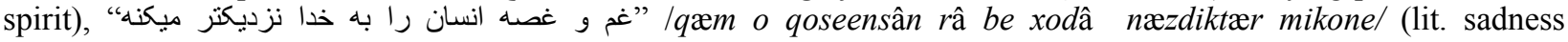
approximates human to God).

\subsection{Burden metaphor}

"SADNESS IS A BURDEN" conceptual metaphor is regular in both Persian and English. In this metaphor sadness is considered as a heavy burden imposed on the sad person. English metaphorical expression "he staggered under sadness" illustrates sadness as a heavy burden that takes human's balance and make him unable to walk or move in a balance way. In Persian expressions such as, "زير بار غم كمرش خم شده" /zire bâ re qæm kæmæreš xæm šode/ (lit. he has

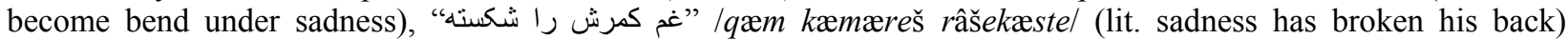
demonstrate the heavy weight of sadness on human back and the other expression " sængini dær sine dâ ræd/ (lit. having heavy sadness in chest) show the heavy weight of sadness in person's chest. The metaphorical expression in this group (source domain) is partially the same in Persian and English.

\subsection{Atmosphere metaphor}

"SADNESS IS ATMOSPHERE" is conventional in both Persian and English. It is identified by Barcelona (1986). The research data illustrates the atmosphere metaphor. English metaphorical expression "Atmosphere changed from happily singing to ghastly sadness" and "Atmosphere of peace becomes tinged with sadness" and Persian

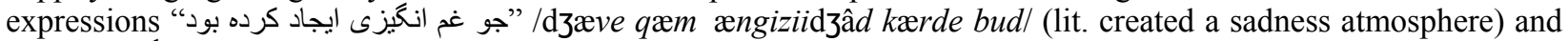
"جو خانه را غم انكيز كرده بود" /d3ævexune râqæm ængiz kærde bud/ (lit. the atmosphere of home changed into sadness) show this metaphorical mapping. All atmosphere metaphor in English can be rendered in to Persian having identical metaphorical meaning.

\subsection{Natural force metaphor}

In "SADNESS IS A NATURAL FORCE" metaphor, sadness is depicted as a destructive natural force. In Persian

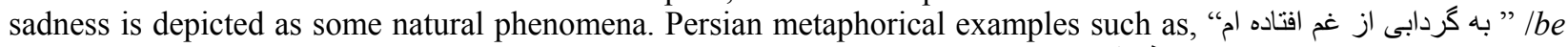

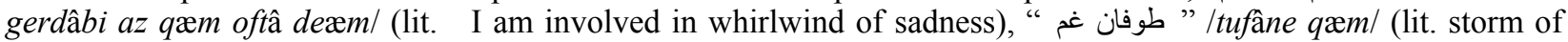

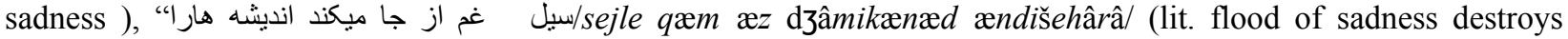

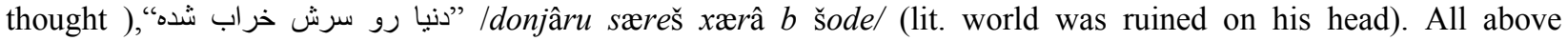
mentioned examples demonstrate that sadness is a destructive phenomenon such as, storm, earthquake, flood, and whirlwind in Persian, similarly, English uses the expressions like "a laugh in the sea of sadness" and "waves of depression came over him" representing sadness as a sea. The present research data reveals that 'natural force' metaphor is more common in Persian than English.

\subsection{Insanity metaphor}

As Kovecses (2000:74) states that the intense emotion is a state of ultimate lack of control. In "INSANITY" metaphor a normal person becomes insane as a result of the intense psychological force. Consequently, $t$ would be more precise to restate the "EMOTION IS INSANITY" metaphor as "THE EFFECT OF INTENSE EMOTIONAL STATE IS INSANTY". It applies to intense emotions like anger, sadness, fear and love. Intense sadness leads a rational and normal person to loss his control and to show insane and irrational behavior. This conceptual metaphor reveals by research data as "SADNESS IS INSANITY" and because intense sadness affect senses like seeing and hearing, so it has a sub metaphor as "SADNESS IS INTERFERENCE WITH ACCURATE PERCEPTION". This metaphor and its sub category are common in both languages under study. As it is found by Kovecses (1990) "STRONG EMOTIONS ARE MADNESS", it is true in the case of intense sadness in sad person. Because of lack of

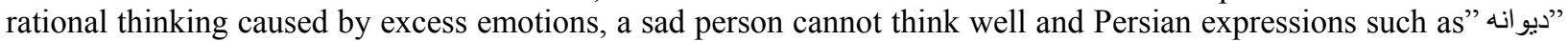

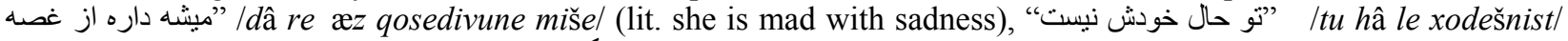
( lit. she is not in her normal state), and "هزيون ميكه"/hæzjunmige/ (lit. he is delirious) are the examples of insanity and madness of a sad person. Similarly, English uses this metaphor in conceptualizing sadness. English expressions "He was insane with grief", "He's out of his mind with grief" and "My outlook was clouded with grief" show the insanity metaphor and interference with accurate perception as the consequence of madness.

\subsection{Illness metaphor}

According to Kovecses (2000: 44) emotions can be judged to be positive or negative. Emotions that are viewed as negative in some senses are partially understood as illness, hence, another conventional metaphor for sadness in Persian and English is the metaphor "SADNESS IS AN ILLNESS". Many metaphorical expressions in Persian and English represent this metaphor. English expressions "She was heart-sick", "Time heals all sorrows", and "For all the sadness she was suffering now" are the examples of illness metaphor foe sadness. Similarly, Persian employs this metaphor in conceptualizing sadness. Persian metaphorical expressions such as, "طبيبان جملكى كر بر مداواى غم كوشند"

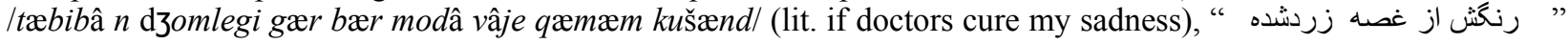


/rængešæz qose zærdšode/ ( his color became yellow with sorrow), and “ غم بينو ايان رخم زرد كرد" / qæme binævâ jân roxæ $m$ zærd $k æ r d /$ (lit. the poor's sadness made my face yellow).

\section{Conclusion}

Having observed the comparative analysis, it was revealed that most of the sadness tangible metaphors are shared by Persian and English such as "SADNESS IS DOWN", "SADNESS IS ILLNESS", "SADNESS IS INSANITY", "SADNESS IS NATURAL FORCE", and "SADNESS IS DARK"; however, some cultural differences were observed due to existence/non-existence of metaphors. Furthermore, the percentages of the three patterns (TS= $44.5 \%, \mathrm{PS}=47 \%, \mathrm{TD}=8.5 \%$ ) revealed that the most frequent pattern in the case of sadness in the two languages under study was the pattern of partially the same ( $\mathrm{PS}=47 \%)$, that is, their underlying conceptual metaphors are the same but their linguistic manifestations or literal meanings are different in most cases.

\section{References}

Anvary, H. (2004). Farhang-e- Kenayat-e -Sokhan. Tehran, Iran: Sokhan.

Barcelona, A. (1986). The concept of depression in American English.In Z. Kovecses (2005). Emotion concepts: from anger to quilt. A cognitive semantic Perspective. Cognitive Psychopathology, Vol.2, No.3, pp.13-32.

Barcelona, A., \& Soriano, C. (2004). Metaphorical conceptualization in English and Spanish. European Journal of English Studies, Vol.8, No.3, pp. 295-307. http://dx.doi.org/10.1080/1382557042000277403

Dehkhoda, A. (1960). Amsal-Al- Hekam. Tehran, Iran: Amir Kabir.

Gibbs, R. W. Jr. (1994). The poetics of mind: figurative thought, language, and Understanding. Cambridge, England :Cambridge University Press.

Kövecses. (1988). The Language of Love: The Semantics of Passion in Conversational English. Lewisburg London.Toronto: Bucknell University Press.

Kovecses, Z. (1986). Metaphors of Anger, Pride, and Love. Pragmatics and Beyond. Amsterdam: John Benjamins.

Kovecses, Z. (1990). Emotion concepts. Berlin and New York: Springer-Verlag. http://dx.doi.org/10.1007/978-1-4612-3312-1

Kövecses, Z. (1991). Happiness: A definitional effort. Metaphor and Symbolic Activity, Vol. 6, No.1, pp.29-46. http://dx.doi.org/10.1207/s15327868ms0601_2

Kovecses, Z. (1995). Anger: Its language, conceptualization, and physiology in the light of cross-cultural evidence, In John R. Taylor, \& Robert E. MacLaury (Eds.) Language and the Cognitive Construal of the World (pp. 181-196). Berlin/New York: Mouton de Gruyter. http://dx.doi.org/10.1515/9783110809305.181

Kovecses, Z. (2000). Metaphor and emotion: Language, culture, and body in human feeling. New York: Cambridge University Press.

Kovecses, Z. (2002). Metaphor: a practical introduction. Oxford: Oxford University Press.

Kovecses, Z. (2003). Metaphor and linguistic expressions. In Z. Kovecses (2005) Metaphor in Culture Universality and Variation (pp. 130-140). Cambridge: Cambridge University Press.

Kovecses, Z. (2005). Emotion concepts: from anger to quilt. A cognitive semantic Perspective. Cognitive Psychopathology, Vol. 2, No. 3, pp. 13-32.

Kovecses, Z. (2005). Metaphor in Culture. Universality and Variation. New York/ Cambridge: Cambridge University Press. http://dx.doi.org/10.1017/CBO9780511614408

Lakoff, G. (1987). Image Metaphors. Metaphor and symbolic activity, Vol.2, No. 3, pp. 219-222. http://dx.doi.org/10.1207/s15327868ms0203_4

Lakoff, G. (1993). The Contemporary Theory of Metaphor. In A. Ortony (Ed.), Metaphor and thought, (pp. 202-251). Cambridge: Cambridge University Press. http://dx.doi.org/10.1017/CBO9781139173865.013

Lakoff, G., \& Johnson, M. (1980). Metaphors we live by. New York \& Chicago: Chicago University Press.

Lakoff, G., \& Kovecses, Z. (1987). The cognitive model of anger inherent in American English. In D. Holland, \& N. Quinn (eds) Cultural models in language and thought (pp. 195-221). Cambridge: Cambridge University Press. http://dx.doi.org/10.1017/CBO9780511607660.009

Matsuki, K. (1995). Metaphors of anger in Japanese. In J. Taylor \& R.E. Maclaury (Eds.), Language and the Cognitive Construal of the World (pp.137-151). Berlin: Mouton de Gruyter. http://dx.doi.org/10.1515/9783110809305.137

Wenfeng, L. (2008). Chou (Sadness) in Chinese and English Writings: an experimental study. Canadian Academy of Oriental and Occidental Culture. Vol.4, No.1, pp. 44-51.

Yu, N. (1995). Metaphorical expressions of anger and happiness in Chinese and English. Metaphor and Symbol, Vol.10, pp. 59-92. http://dx.doi.org/10.1207/s15327868ms1002_1 